\title{
QUANTIFICATION OF GROUNDWATER ABSTRACTION USING SWAT MODEL IN HAKRA BRANCH CANAL SYSTEM OF PAKISTAN
}

\author{
Muhammad Shafeeque ${ }^{1}$, Muhammad Jehanzeb Masud Cheema ${ }^{1,2, *}$, Abid Sarwar ${ }^{1}$ \\ and Muhammad Waqas Hussain ${ }^{3}$ \\ ${ }^{1}$ Department of Irrigation and Drainage, University of Agriculture, Faisalabad, Pakistan; \\ ${ }^{2}$ USPCAS-AFS, University of Agriculture, Faisalabad, Pakistan; ${ }^{3}$ NESPAK, Lahore, Pakistan. \\ "Corresponding author's e-mail: mjm.cheema@uaf.edu.pk
}

\begin{abstract}
Agriculture of arid and semi-arid regions is effected by over extraction of groundwater (GW) around the world especially in the developing countries like Pakistan. Groundwater (GW) should be properly recharged to overcome the issue of declining water levels. Analysis of GW use against recharge is done to address the issues of sustainable management and aquifer mining in Hakra branch canal system off-taking Eastern Sadiqia canal of Pakistan. Various water balance components were computed to estimate the net recharge using modeling as well as with remote sensing techniques. Soil profile data, water table depths, canals off take discharges and all the climatic data for the year 2006-11 were used as input data sets in Soil and Water Assessment Tool (SWAT) to compute GW recharge. Hakra branch canal system is divided into 17 off-taking distributaries and direct water courses. The SWAT model is calibrated and validated using in situ extents of soil, vegetation, evapotranspiration and surface supplies. Nash-Sutcliffe Efficiency (NSE) and coefficient of determination $\left(\mathrm{R}^{2}\right)$ were used as statistical parameters for calibration and validation of results. Using the net recharge, net GW abstraction was calculated for entire command area of Hakra branch canal system. SWAT was calibrated (NSE $=0.97, \mathrm{R}^{2}=0.87$ ) for the period of 2006-08 and validated $\left(\mathrm{NSE}=0.98, \mathrm{R}^{2}=0.90\right.$ ) for the period 2009-11. Average net recharge to the GW aquifer for the whole command area is estimated at $-91 \mathrm{~mm} \mathrm{yr}^{-1}$, indicating abstraction is greater than recharge from all sources. Whereas, average net GW abstraction is calculated as $712 \mathrm{~mm} \mathrm{yr}^{-1}$ in the study area. The GW abstraction trend is increasing in the tail distributaries due to less canal water supplies. It is recommended to increase the head discharge of the main canal and share of the tail distributaries.
\end{abstract}

Keywords: Groundwater recharge, groundwater abstraction, irrigated agriculture, irrigation efficiency, SWAT.

\section{INTRODUCTION}

Irrigated agriculture of Pakistan is mainly dependent on irrigation water from all three major resources i.e. rainfall, surface water (SW) and groundwater (GW). Agriculture sector covers about $20.9 \%$ of gross domestic product (GDP) of the country (GOP, 2015). As Pakistan lies in arid to semiarid region and rainfall only is not sufficient to fulfill the crop water requirements (CWR). About $95 \%$ of available water resources in the country are being used by agriculture, this practice depleting these precious treasures (GOP, 2014). Irrigation efficiency of our system is also very low i.e. 35\% (Hussain et al., 2011) and cropping intensity is double than capacity of irrigation system (WAPDA, 2011). Thus, CWR are not covered with this less efficient irrigation system resulting in extensive use of groundwater (GW) for irrigation (Qureshi, 2004). The groundwater fulfils 50-65\% demand of agriculture in conjunction with surface water or separately (Qureshi, 2004). UNESCO (2003) indicated that 80\% of extracted groundwater is being used for growing crops. This valuable resource is in danger due to mishandling (Wada et al., 2010; Treidel et al., 2012). To ensure sustainability of
$\mathrm{GW}$, systematic quantification of its abstraction and recharge is required (Awan et al., 2013).

Various piezometer based methods and hydrological models are available for this purpose, however, there are merits and demerits of using these models. For example, Piezometer based approach to measure abstraction/recharge needs a well distributed network of piezometers and continuous monitoring (Ahmad et al., 2009; Zaidi et al., 2007) also groundwater models are based on in-situ data on water table depths. The Soil and Water Assessment Tool (SWAT) model (Arnold et al., 1998) is one of the model that is being used extensively for water balance studies and water quality modeling. SWAT model is based on different climatic inputs including; precipitation; maximum and minimum temperature, solar radiation data, relative humidity, and wind speed, different soil types and Land use and land cover (LULC), and has potential to determine the crop water demand for each hydrological response unit (HRU) (Awan et al., 2013). The groundwater abstraction can also be determined as a residual term in the SWAT water balance equation (Cheema et al., 2014). 
The main objective of the study is to determine net groundwater recharge and abstraction from the command area of Hakra branch canal system (HBCS). This GW recharge and abstraction has been quantified using SWAT model and algorithmic water balance approach. This quantification of $\mathrm{GW}$ is helpful for indicating the areas where GW is being used in abundance and causing problems of declining of GW table and secondary salinization due to over abstraction and less recharge. This would help in developing framework to recharge and abstract GW in a sustainable way.

\section{MATERIALS AND METHODS}

Hakra branch canal off-takes its discharge from Eastern Sadiqia Canal (at RD 245+000). Design discharge of Hakra canal is $82 \mathrm{~m}^{3} \mathrm{sec}^{-1}$ and total length is $92 \mathrm{~km}$. Total length of the Hakra branch canal distribution network is about 644159 $\mathrm{m}$. It has 457 water courses including 45 direct outlets. There are 17 major distributaries and 27 minors, sub-minors and direct water courses. There are 11 observation wells installed in the study area from which the depth of the water table is being measured (WAPDA, 2011).
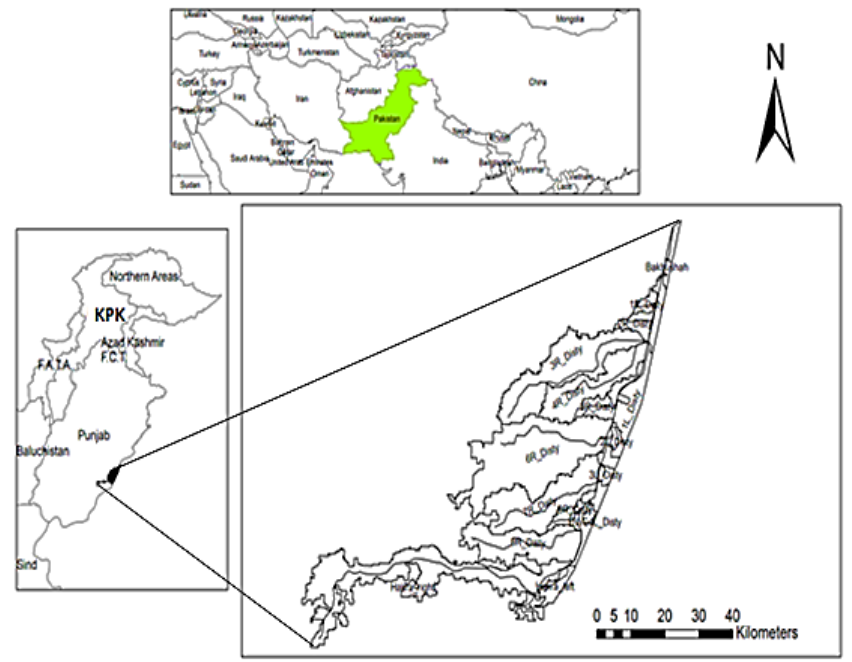

Figure 1. Geographical location of Hakra branch canal system.

Figure 1 shows the geographical location of command area of Hakra branch canal. The climate of the area is characterized by large seasonal fluctuations in temperature and rainfall. The mean maximum and minimum temperatures are being $42.2^{\circ} \mathrm{C}$ and $0^{\circ} \mathrm{C}$, respectively. The average annual rainfall is $59 \mathrm{~mm}$ $\mathrm{yr}^{-1}$ (PMD, 2011; http://nwfc.pmd.gov.pk).

The water table in the project area ranged from less than $1 \mathrm{~m}$ to about $25 \mathrm{~m}$ (WAPDA, 2011). There are 11 observation wells installed in the study area from which the depth of the water table was measured. The major crops of the study area include wheat, cotton, sugarcane, fodder and rice. Yields per hectare in tones are; for rice 1.6 , cotton 1.3 , wheat 1.9 and sugarcane 30 tones $\mathrm{ha}^{-1}$. The cropping intensity is $129 \%$ on annual basis $($ Kharif $=55 \%$, Rabi $=74 \%)$ (WAPDA, 2011). SWAT model has been used in many studies (Pikounis et al., 2003; Sun and Cornish, 2005; Schuol et al., 2008; Chung et al., 2010) to simulate various water management strategies. SWAT model can also estimate the GW recharge (Arnold et al., 1993) and groundwater abstractions (Cheema et al., 2014). The water balance (WB) equation in the SWAT model is given as (Neitsch et al., 2005):

$$
\mathrm{SW}=\mathrm{SW}_{\mathrm{i}}+\Sigma\left(\mathrm{P}-\mathrm{Q}-\mathrm{ET}_{a}-\mathrm{W}-\mathrm{Q}_{\mathrm{r}}\right)
$$

Where; $\mathrm{SW}$ and $\mathrm{SW}_{\mathrm{i}}$ represent the soil water $(\mathrm{mm}), \mathrm{P}=$ rainfall $(\mathrm{mm}), \mathrm{Q}=$ runoff $(\mathrm{mm}), \mathrm{ET}_{a}=$ actual evapotranspiration $(\mathrm{mm}), \mathrm{W}=$ water vadose zone $(\mathrm{mm})$ and $\mathrm{Q}_{\mathrm{r}}=$ return flow $(\mathrm{mm})$. Detailed documentations can be found in the SWAT theoretical manual (Neitsch et al., 2005).

The Hakra branch canal system is considered as an artificial watershed with 17 sub-basins. These sub-basins are the culturable command areas (CCAs) of 17 distributaries. The detail of these distributaries is given in Table 1 and shown in Figure 1.

LULC data, Digital Elevation Model (DEM) and soil data were used to find out the hydrological parameters for each sub-basin (Di Luzio et al., 2002). LULC of the study area, developed by Cheema and Bastiaanssen (2010) was used. The DEM data was downloaded from http://srtm.csi.cgiar.org and shown in Figure 2. International Water Management Institute helped to obtain soil data, classified according to textural properties. Meteorological data was obtained from the Pakistan Metrological Department for the period of 20062011 of Bahawalnagar (BN) station.

his station is located within the command area of Hakra Branch Canal System (HBCS).

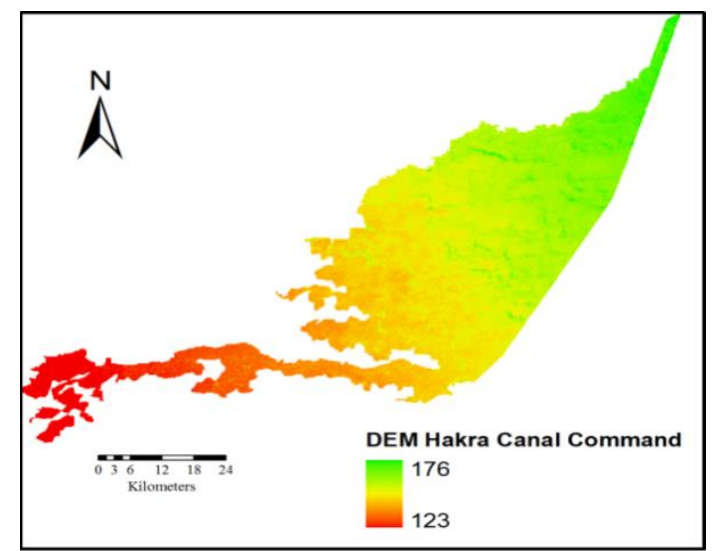

Figure 2. Digital Elevation Model (DEM) in meters (m) for HBCS. 
Daily discharge data was obtained from Punjab Irrigation Department for all the distributaries. Data from 2006 to 2011was used to calculate the actual depth of available water in order to formulate irrigation schemes within the command areas. The monthly mean maximum and minimum temperature and average precipitation for the study area is given in Figure 3.

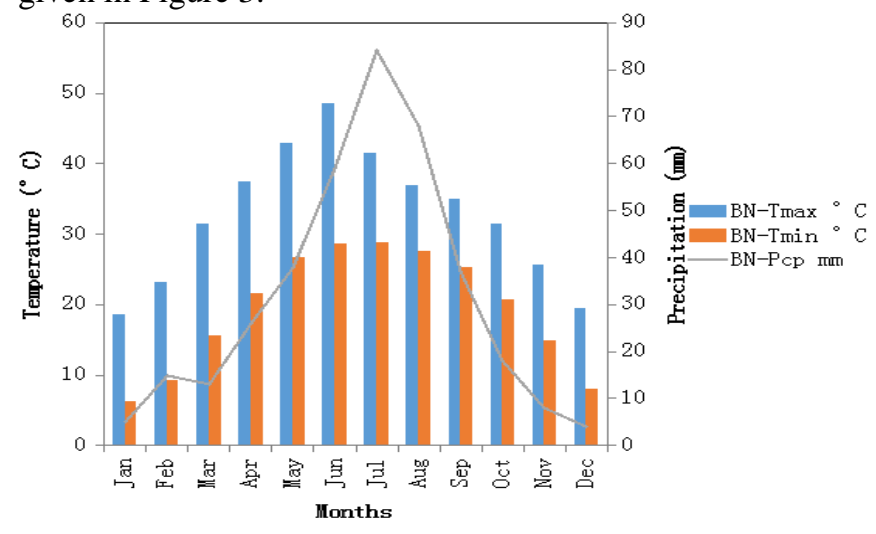

Figure 3. Mean monthly maximum and minimum temperature and average monthly precipitation of Bahawalnagar (BN) station located in the command area HBCS.

The SWAT model was calibrated for the period from 2006 to 2008 and validated for the period 2009-2011 against the net recharge calculated by hydrological equation. Manual calibration of SWAT model was based on hit and trial method. Predictive performance of SWAT was evaluated by coefficient of determination $\left(\mathrm{R}^{2}\right)$ and Nash-Sutcliffe Efficiency (NSE), as used by various researchers (e.g. Santhi et al., 2001; Grizzetti et al., 2003; Sintondji, 2005; Wu and $\mathrm{Xu}, 2006$; Chekol, 2006; Abraham et al., 2007; Parajuli et al., 2009):

$$
\begin{gathered}
\mathrm{NSE}= \\
\mathrm{R}^{2}=
\end{gathered}
$$

Where $\mathrm{X}$ is the observed data; $\mathrm{X}_{\mathrm{m}}$ is the mean of observed data; $\mathrm{Y}$ is model data and $\mathrm{Y}_{\mathrm{m}}$ is the mean of the model data. The gross GW abstraction was calculated using relationship given below:

Gross GW abstraction $=\mathrm{ET}_{a}-($ Surface water + Rainfall $)(4)$

Overall irrigation efficiency for surface water was used as $35 \%$ (Hussain et al., 2011). Method was used to calculate the effective rainfall for the cropped area. The contribution of rainfall into $\mathrm{ET}_{a}$ was taken as $80 \%$ of total rainfall and the other $20 \%$ was used to recharge GW. Gross GW use efficiency was taken as $70 \%$ as there are negligible or minor conveyance losses and application efficiency in Pakistan is $75 \%$ (Hussain et al., 2011). Net GW abstraction was determined using equation:

Net GW abstraction = Gross GW abstraction - Net recharge

Table 1. Area (ha) of each distributary, total area of Hakra canal command, observation wells and distribution of

\begin{tabular}{|c|c|c|c|c|}
\hline Distributary & GCCA (ha) & CCA (ha) & Location & Observation wells \\
\hline Baku Shah Disty & 615 & 609 & Head & 3_S \\
\hline Mubarik (1L) Disty & 7518 & 6920 & Head & PL_XIV_40 \\
\hline Sundar (1R) Disty & 2062 & 2010 & Head & W_3 \\
\hline Mianwala (2L) Disty & 1964 & 1770 & Head & \\
\hline Dunga Bunga (2R) Disty & 2149 & 2148 & Head & \\
\hline Malkir (3L) Disty & 722 & 703 & Head & \\
\hline Khatan (3R) Disty & 45945 & 29455 & Head & \\
\hline Kamrani (4L) Disty & 855 & 682 & Middle & 7_S \\
\hline Haroonabad (4R) Disty & 28249 & 17593 & Middle & 8_S \\
\hline Bhagsen (5R) Disty & 4271 & 3715 & Middle & W_2 \\
\hline Mamun (6R) Disty & 49821 & 41222 & Middle & W_4 \\
\hline Khichiwala (7R) Disty & 26770 & 21804 & Middle & W_5 \\
\hline Josar (8R) Disty & 2912 & 2574 & Middle & W_6 \\
\hline Sardrewala (9R) Disty & 20206 & 19917 & Tail & CLXXI_8 \\
\hline Hakra Left Disty & 2457 & 2419 & Tail & CLXXI_4 \\
\hline Hakra Right Disty & 45485 & 42911 & Tail & \\
\hline Flood Channel Disty & 9141 & 6687 & Tail & \\
\hline Total & 251142 & 203139 & & 11 Wells \\
\hline
\end{tabular}
command area into head, middle and tail. 
The GW abstraction used in Eq. 5 was $30 \%$ more than that of GW contribution (calculated in Eq. 4) to $\mathrm{ET}_{a}$ as irrigation efficiency of groundwater was taken as $70 \%$. Net recharge was the output of SWAT model with consideration of all the meteorological and soil parameters. The net recharge and groundwater abstraction was verified by comparing groundwater level (GWL) in 2006 and GWL in 2011.

\section{RESULTS AND DISCUSSION}

The SWAT model was calibrated for the period of 2006-08 and validated for period 2009-11 for net recharge estimation against the net recharge calculated. The value for NSE and $\mathrm{R}^{2}$ after final run of calibration (2006-2008) is 0.98 and 0.87 , respectively (Fig. 4). For validation (2009-2011), NSE and R ${ }^{2}$ are 0.98 and 0.90 , respectively (Fig. 5). These values show that model results are good and estimated net recharge values are reliable (Saleh et al., 2004; Singh et al., 2005; Moriasi et al., 2007; Cheema et al., 2014).

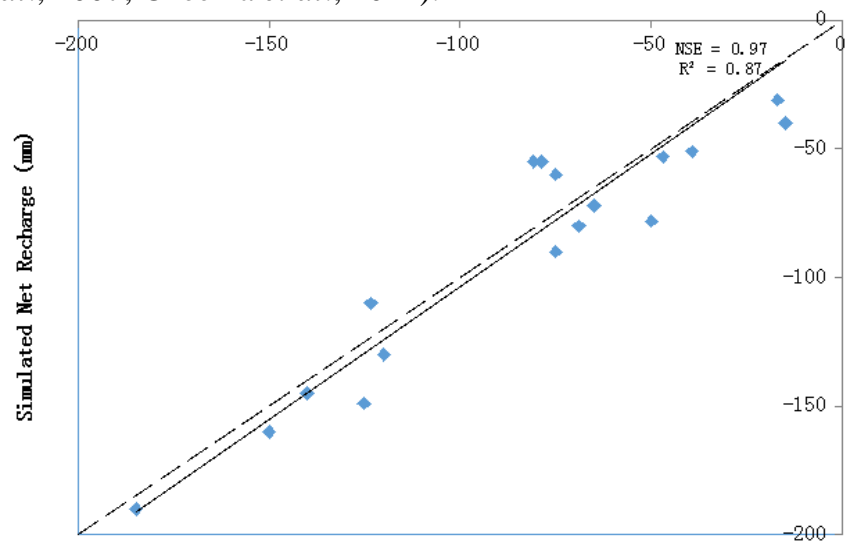

Calculated Net Recharge (mm) through Hydrologic equation

Figure 4. Calibration of SWAT model for net recharge.

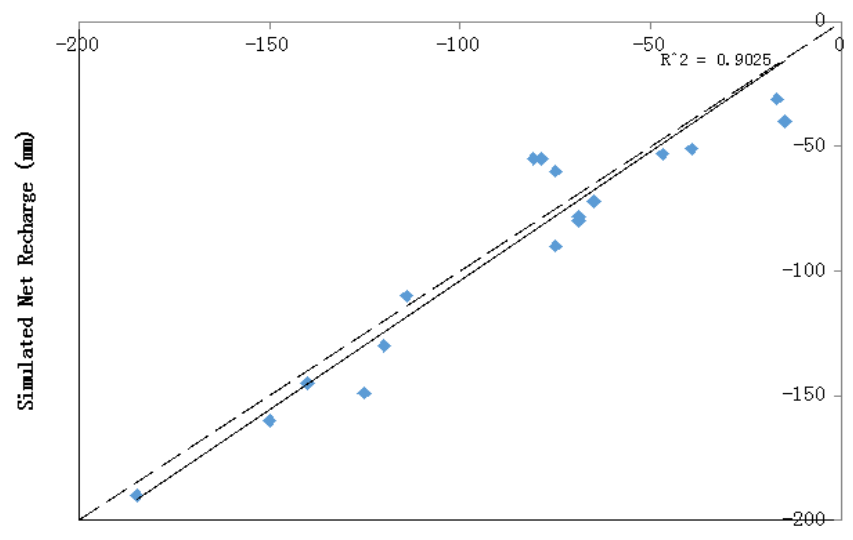

Calculated Net Recharge (mm) through Hydrologic equation

Figure 5. Validation of SWAT model for net recharge.
The mean annual $\mathrm{ET}_{a}$ estimated by SWAT model is high in HBCS. The maximum $\mathrm{ET}_{a}$ is estimated at $1064 \mathrm{~mm}$ for $1 \mathrm{R}$ distributary and minimum $\mathrm{ET}_{a}, 871 \mathrm{~mm}$ for Hakra Right Distributary (Fig. 6).

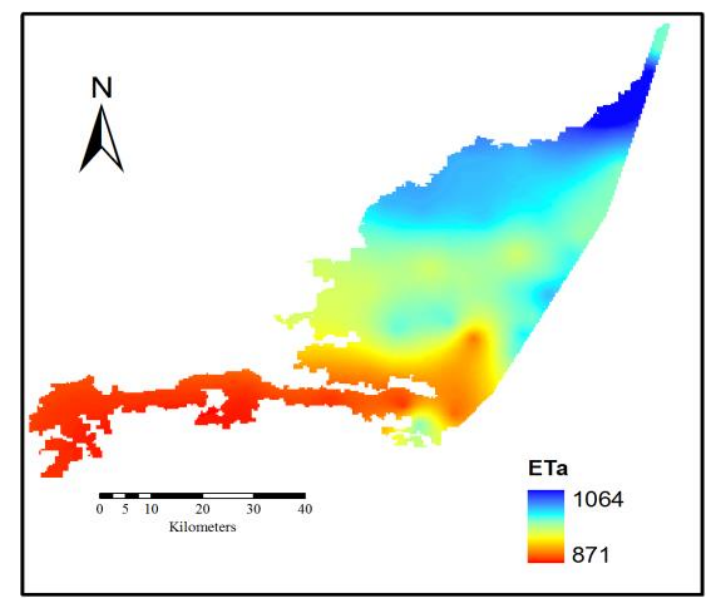

Figure 6. Mean annual actual evapotranspiration (mm) estimated by SWAT for HBCS.

These results indicate that $\mathrm{ET}_{a}$ is higher at head distributaries as compared to tail. The main reason of this less $\mathrm{ET}_{a}$ is supposed due to shortage of irrigation supplies.

Figure 7 describes the results of main components of water balance of HBCS. The average values for $\mathrm{ET}_{a}$ at the head, middle and tail areas are $853 \mathrm{~mm}, 793 \mathrm{~mm}$ and $700 \mathrm{~mm}$, respectively. While, average surface water supplies at head, middle and tail are $320 \mathrm{~mm}, 282 \mathrm{~mm}$ and $159 \mathrm{~mm}$, respectively. The irrigation water supply at head is more and gradually decreases towards the tail areas.

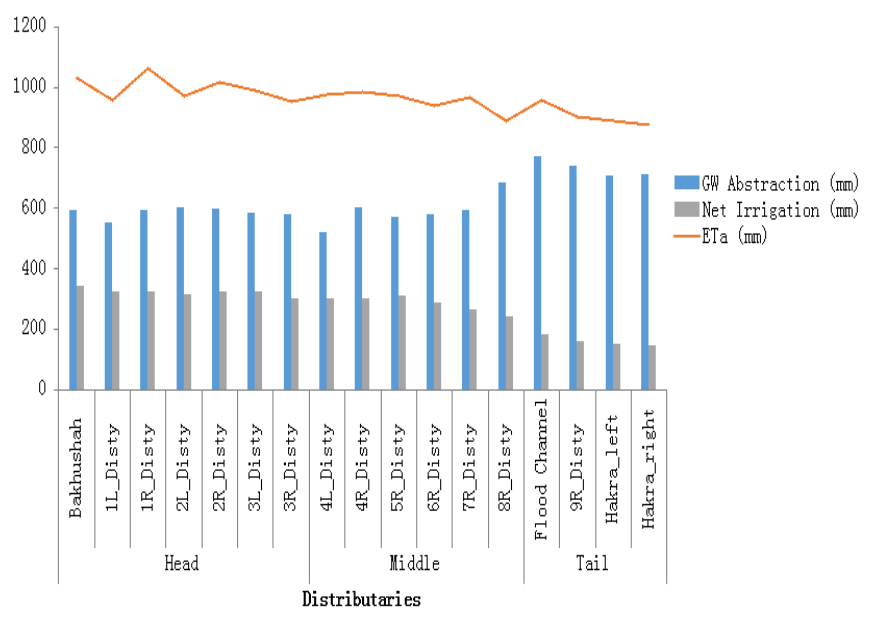

Figure 7. Water balance component estimated using SWAT for HBCS. 
It implies that net contribution from surface supplies is lower than the demand. Therefore, extensive groundwater abstractions are being made in the CCA to supplement surface supplies. The mean annual gross $\mathrm{GW}$ abstraction estimated using Eq 5 is provided in the Figure 8. It is evident from the Figure 8, that GW is being abstracted at higher rate in the tail head areas as compared to the head.

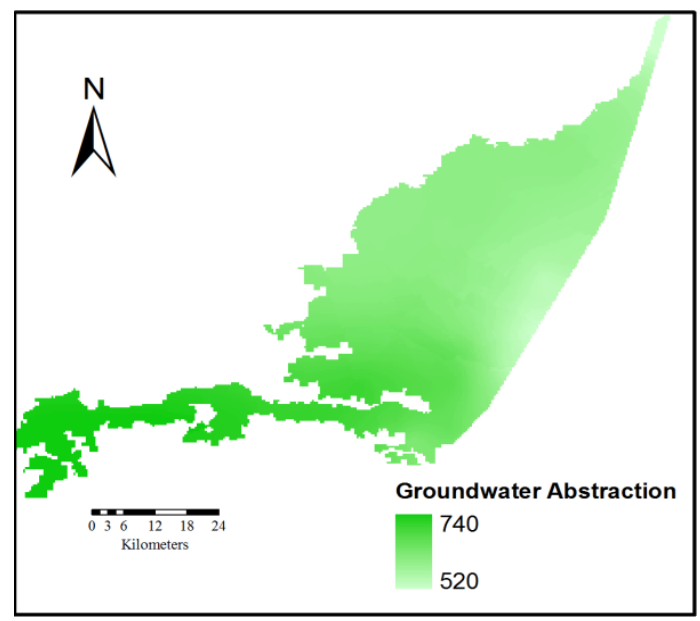

Figure 8. Gross groundwater abstraction (mm) used to fulfill crop water requirement.

The annual mean net recharge estimated using SWAT, for all 17 sub basins in HBCS in shown in Figure 9. Net recharge is higher in the head areas and showing a decreasing trend towards the tail. Mean net recharge for head, middle and tail is estimated at $-55 \mathrm{~mm},-107 \mathrm{~mm}$ and $-130 \mathrm{~mm}$, respectively. Whilst $-91 \mathrm{~mm}$ is average value for entire HBCS.

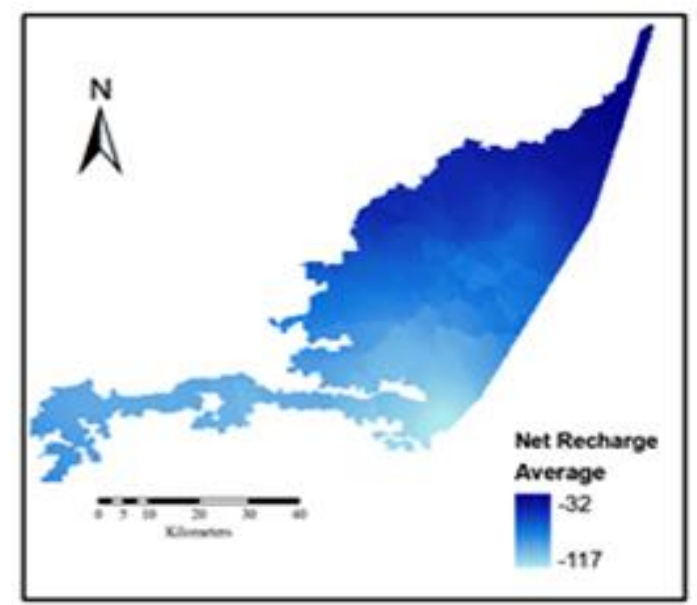

Figure 9. Mean net GW recharge (mm) in HBCS estimated for the years 2006-11.
Net GW abstraction estimated using Eq 5 and shown in Figure 10 , provides evidence that net $\mathrm{GW}$ abstraction is higher at tail areas of the canal command. The average for head, middle and tail is $640 \mathrm{~mm}, 698 \mathrm{~mm}$ and $861 \mathrm{~mm}$, respectively.

These values of net recharge and net GW abstraction were verified by comparing groundwater depths (GWD) in 2006 and 2011. Observed values of GWD-2006 and GWD-2011 were taken from the piezometers installed in the study area by WAPDA with piezometers in distributaries of head, middle and tail areas. Figure 11 shows GWD in 2006 and 2011, as well as estimated GWD for the year 2011 GWD by incorporating net recharge. Estimated and observed GWD for the year 2011 is in good agreement having co-efficient of determination $\left(\mathrm{R}^{2}\right)$ estimated at 0.97 (not shown). A continues decrease in GWD is observed from 2006 to 2011. Cheema et al., 2014, observed similar trends during the year 2007.

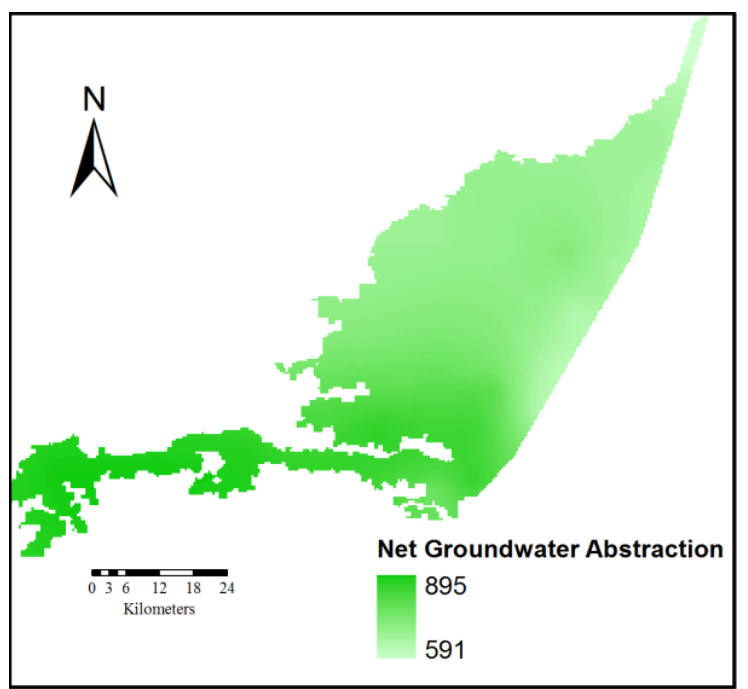

Figure 10. Mean net $G W$ abstraction $(\mathrm{mm})$ for averaged from 2006 to 11 in $\mathrm{HBCS}$.

The spatially quantified net GW abstraction can be used in decision making to develop policy for recharging $\mathrm{GW}$ and to formulate law about GW abstraction. The study shows that there is scarcity of surface water in the command areas of tail distributaries as well as in the areas of tails for middle distributaries. Lining of canal banks and watercourses is recommended for whole HBCS in addition to increasing the head discharge for Hakra branch and share of tail distributaries. Installation of tubewells is recommended for abstracting the seeped water near the head of each distributary. This pumped water should be taken to the tail areas to increase availability of fresh water in the tail areas. 


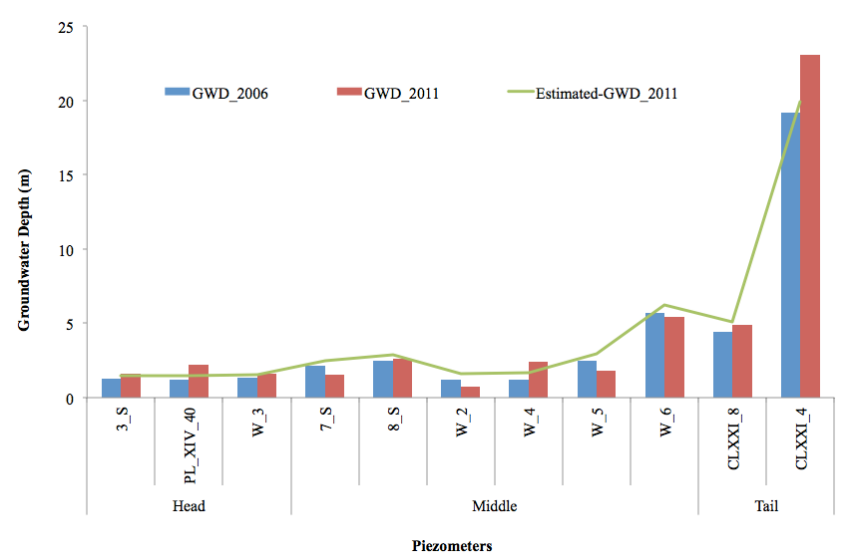

Figure 11. Groundwater depth observed and estimated in the command areas of head, middle and tail of HBCS.

As most of the land in the tail distributaries is affected with salinity so more surface water is required to leach down these excessive salts. That is why abstraction of GW should be minimized in these areas for preventing the soils from the worst condition of secondary salinization. Salt tolerant and low delta crops should be encouraged to cope with the problem of shortage of water and salinity. There must be legislation for installation of tube wells, abstraction quantity and crops sown according to the availability and quality of water $(\mathrm{SW}+\mathrm{GW})$, and soil condition.

To resolve the issue of quantity and quality, conjunctive use may be the option (Ahmad et al., 2002; Kazmi et al., 2012; Singh, 2014). But the farmers must know the exact mixing ratios according to the availability of fresh surface water and GW conditions. A conjunctive water management framework should be developed for whole HBCS by keeping in mind the situation of SW and GW as well as requirements of upstream and downstream water users within the HBCS. Conjunctive water management is capable of optimizing groundwater recharge (Wu et al., 2015). Conjunctive water management frame work will induce a recharge framework in the HCS to safe the GW as well as land from secondary salinization.

Conclusion: It is concluded that the command areas of tail distributaries are the most affected by surface water shortage thus resulting in huge amount of water being extracted from ground. Average net recharge to the GW aquifer for the whole command area is estimated at $-91 \mathrm{~mm} \mathrm{yr}^{-1}$, indicating abstraction is greater than recharge from all sources. Average net $\mathrm{GW}$ abstraction is calculated as $712 \mathrm{~mm} \mathrm{yr}^{-1}$ in the study area. Proper recharge framework in the HBCS should be developed to overcome the issue of over exploitation of GW. If groundwater extraction is deemed necessary, a mechanism of parallel extraction from head to tail should be developed to make ground resources in equitable position and recharge from the canal to extend in the whole reach which will help for solving burning issue of salinity in the Hakra branch canal system, resulted by over and uneven exploitation of groundwater resources.

Acknowledgement: Authors are thankful to Punjab Irrigation Department, Pakistan Metrological Department and International Water Management Institute (IWMI), for their support in data acquisition. We are also thankful to anonymous reviewers for their constructive comments.

\section{REFERENCES}

Abraham, L.Z., J. Roehrig and D.A. Chekol. 2007. Calibration and validation of SWAT hydrologic model for Meki watershed, Ethiopia. Paper presented at Conference on International Agricultural Research for Development, University of Kassel-Witzenhausen and University of Gottingen, Germany.

Ahmad, M.D., H. Turral and A. Nazeer. 2009. Diagnosing irrigation performance and water productivity through satellite remote sensing and secondary data in a large irrigation system of Pakistan. Agric. Water Manage. 96: 551-564.

Arnold, J.G., P.M. Allen and G. Bernhardt. 1993. A comprehensive surface-groundwater flow model. J. Hydrol. 142: 47-69.

Arnold, J.G., R. Srinivasan, R.S. Muttiah and J.R. Williams. 1998. Large-area hydrologic modeling and assessment: Part I. Model development. J. Am. Water Res. Assoc. 34: 73-89.

Awan, U.K., B. Tischbein and C. Martius. 2013. Combining hydrological modeling and GIS approaches to determine the spatial distribution of groundwater recharge in an arid irrigation scheme. Irrig. Sci. 31: 793-806.

Cheema, M.J.M., W.G.M. Bastiaanssen and W.W. Immerzeel. 2014. Spatial quantification of groundwater abstraction in the irrigated Indus basin. GWAT 52:25-36.

Cheema, M.J.M. and W.G.M. Bastiaanssen. 2010. Land use and land cover classification in the irrigated Indus Basin using growth phenology information from satellite data to support water management analysis. Agric. Water Manage. 97: 1541-1552.

Chekol, A.D. 2006. Modeling of Hydrology and Soil Erosion of Upper Awash River Basin, Ethiopia, PhD Thesis; University of Bonn, Germany.

Chung, I., N. Kim, J. Lee and M. Sophoceous. 2010. Assessing distributed groundwater recharge rate using integrated surface water-groundwater modelling: 
Application to Mihocheon watershed, South Korea. Hydrogeol. J. 18: 1253-1264.

Di Luzio, M., R. Srinivasan and J.G. Arnold. 2002. Integration of watershed tools and SWAT model into BASINS. Am. Water Res. 38: 1127-1141.

GOP. 2014. Economic survey of Pakistan. Economic Affairs Division. Government of Pakistan.

GOP. 2015. Economic survey of Pakistan. Economic Affairs Division. Government of Pakistan.

Grizzetti, B., F. Bouraoui, K. Granlund, S. Rekolainen and G. Bidoglio. 2003. Modelling diffuse emission and retention of nutrients in the Vantaanjoki watershed (Finland) using the SWAT model. Ecol. Model. 169: 25-38.

Hussain, I., Z. Hussain, H. Maqbool, S.W. Akram and M.F. Farhan. 2011. Water balance, supply and demand and irrigation Efficiency of Indus Basin. Pak. Econ. Soc. Rev. 49: 13-38.

Kazmi, S.I., M.W. Ertsen and M.R. Asi. 2012. The impact of conjunctive use of canal and tube well water in Lagar irrigated area, Pakistan. Phys. Chem. Earth. 48: 86-98.

Moriasi, D.N., J.G. Arnold, M.W. Van Liew, R.L. Bingner, R.D. Harmel and T.L. Veith. 2007. Model evaluation guidelines for systematic quantification of accuracy in watershed simulations. ASABE 50: 885-900.

Neitsch, S.L., J.G. Arnold, J.R. Kiniry, R. Srinivasan and J.R. Williams. 2005. Soil and water assessment tool input/output file documentation, Version 2005. USDAARS Grassland, Soil and Water Research Laboratory, Temple, Tex. Available online at www.brc.tamus.edu/swat/doc.html

Parajuli, P.B., K.R. Mankin and P.L. Barnes. 2009. Source specific fecal bacteria modeling using soil and water assessment tool model. Bioresour. Technol. 100: 953963.

Pikounis, M., E. Varanou, E. Baltas, A. Dassaklis and Mimikou. 2003. Application of the SWAT model in the Pinios River basin under different land-use scenarios. Global Nest J. 5: 71-79.

Qureshi, A.S., H. Turral and I. Masih. 2004. Strategies for the management of conjunctive use of surface water and groundwater resources in semi-arid areas: a case study from Pakistan. Research Report 86. International Water Management Institute (IWMI). Colombo, Sri Lanka.

Saleh, A. and B. Du. 2004. Evaluation of SWAT and HSPF within BASINS program for the upper North Bosque River watershed in central Texas. Trans. ASAE 47: 10391049.

Santhi, C., J.G. Arnold, J.R. Williams, W.A. Dugas, R. Srinivasan and L.M. Hauck. 2001. Validation of the SWAT model on a large river basin with point and nonpoint sources. Am. Water Res. 37: 1169-1188.
Schuol, J., K.C. Abbaspour, R. Srinivasan and H. Yang. 2008. Estimation of freshwater availability in the West African sub-continent using the SWAT hydrologic model. J. Hydrol. 352: 30-49.

Singh, A. 2014. Conjunctive use of water resources for sustainable irrigated agriculture. J. Hydrol. 519: 16881697.

Singh, J., H.V. Knapp, J.G. Arnold and M. Demissie. 2005. Hydrologic modeling of the Iroquois River watershed using HSPF and SWAT. J. Am. Water Res. Assoc. 41: 361-375.

Sintondji, L. 2005. Modelling the rainfall-runoff process in the upper Ouémé Catchment (Terou in Benin republic) in a context of global change: Extrapolation from the local to the regional scale. PhD Thesis, Faculty of Mathematics and the Natural Sciences, University of Bonn, Aachen Germany.

Sun, H. and P.S. Cornish. 2005. Estimating shallow groundwater recharge in the headwaters of the Liverpool plains using SWAT. Hydrol. Process 19: 795-807.

Treidel, H., J.J. Martin-Bordes and J.J. Gurdak (eds.). 2012. Climate change effects on groundwater resources: A global synthesis of findings and recommendations. International Association of Hydrogeologists (IAH) International Contributions to Hydrogeology. Taylor \& Francis publishing, p.414.

United Nations Educational, Scientific and Cultural Organization (UNESCO). 2003. Water for People, Water for Life, United Nations World Water Development Report, Part II: A Look at the World's Freshwater Resources. Available online at www.unesco.org

Wada, Y., L.P.H. van Beek, C.M. van Kempen, J.W.T.M. Reckman, S. Vasak, and M.F.P. Bierkens. 2010. Global depletion of groundwater resources. Geophys. Res. Lett. 37: 20402.

WAPDA. 2011. Hydro Potential in Pakistan. Water and Power Development Authority. Available online at www.wapda.gov.pk

Wu, K. and Y.J. Xu. 2006. Evaluation of the applicability of the SWAT model for coastal watersheds in southeastern Louisiana. J. Am. Water Res. Assoc. 42: 1247-1260.

Wu, X., Y. Zheng, B. Wu, Y. Tian, F. Han and C. Zheng. 2015. Optimizing conjunctive use of surface water and groundwater for irrigation to address human-nature water conflicts: A surrogate modeling approach. Agric. Water Manage. Available online at http://dx.doi.org/10.1016/j.agwat.2015.08.022

Zaidi, F.K., S. Ahmed, B. Dewandel and J.C. Marechal. 2007. Optimizing a piezometric network in the estimation of the groundwater budget: A case study from a crystallinerock watershed in southern India. Hydrogeol. J. 15: 11311145. 